\title{
The Genetic Prehistory of the New World Arctic
}

Maanasa Raghavan ${ }^{1}$, Michael DeGiorgio ${ }^{2}$, Anders Albrechtsen ${ }^{3 *}$, Ida Moltke ${ }^{3,4 *}$, Pontus

Skoglund $^{5,6^{*}}$, Thorfinn S. Korneliussen ${ }^{1}$, Bjarne Grønnow ${ }^{7}$, Martin Appelt ${ }^{7}$, Hans Christian Gulløv ${ }^{7}$, T. Max Friesen $^{8}$, William Fitzhugh ${ }^{9}$, Helena Malmström ${ }^{1,5}$, Simon Rasmussen $^{10}$, Jesper Olsen ${ }^{11}$, Linea Melchior ${ }^{12}$, Benjamin T. Fuller ${ }^{13}$, Simon M. Fahrni ${ }^{13}$, Thomas Stafford Jr. ${ }^{1,11}$, Vaughan Grimes ${ }^{14,15}$, M.A. Priscilla Renouf $^{14^{\wedge}}$, Jerome Cybulski ${ }^{16,17}$, Niels Lynnerup ${ }^{12}$, Marta Mirazon Lahr ${ }^{18}$, Kate Britton ${ }^{15,19}$, Rick Knecht ${ }^{19}$, Jette Arneborg ${ }^{20}$, Mait Metspalu ${ }^{21,22}$, Omar E. Cornejo ${ }^{23,24}$, Anna-Sapfo Malaspinas ${ }^{1}$, Yong Wang ${ }^{25,26}$, Morten Rasmussen ${ }^{1}$, Vibha Raghavan ${ }^{27}$, Thomas V.O. Hansen ${ }^{28}$, Elza Khusnutdinova ${ }^{29,30}$, Tracey Pierre ${ }^{1}$, Kirill Dneprovsky ${ }^{31}$, Claus Andreasen ${ }^{32}$, Hans Lange ${ }^{32}$, M. Geoffrey Hayes ${ }^{33,34,35}$, Joan Coltrain ${ }^{36}$, Victor A. Spitsyn $^{37}$, Anders Götherström ${ }^{38}$, Ludovic Orlando ${ }^{1}$, Toomas Kivisild ${ }^{21,39}$, Richard Villems ${ }^{21,22}$, Michael H. Crawford $^{40}$, Finn C. Nielsen ${ }^{28}$, Jørgen Dissing ${ }^{12}$, Jan Heinemeier ${ }^{11}$, Morten Meldgaard ${ }^{1}$, Carlos Bustamante ${ }^{23}$, Dennis H. O’Rourke ${ }^{36}$, Matthias Jakobsson ${ }^{5}$, M. Thomas P. Gilbert ${ }^{1}$, Rasmus Nielsen ${ }^{25}$, and Eske Willerslev ${ }^{1 \#}$

1. Centre for GeoGenetics, Natural History Museum of Denmark, University of Copenhagen, Øster Voldgade 5-7, 1350 Copenhagen, Denmark.

2. Department of Biology, Pennsylvania State University, 502 Wartik Laboratory, University Park, PA 16802, USA.

3. The Bioinformatics Centre, Department of Biology, University of Copenhagen, Ole Maaloes Vej 5, 2200 Copenhagen N, Denmark.

4. Department of Statistics, The University of Chicago, 5734 S. University Avenue Chicago, IL 60637, USA.

5. Department of Evolutionary Biology, Uppsala University, Norbyvägen 18D, 75233 Uppsala, Sweden.

6. Department of Genetics, Harvard Medical School, 77 Avenue Louis Pasteur, Boston, MA 02115, USA.

7. SILA - Arctic Centre at Ethnographic Collections, The National Museum of Denmark, Frederiksholms Kanal 12, DK-1220 Copenhagen K, Denmark.

8. Department of Anthropology, University of Toronto, 19 Russell St., Toronto, Ontario M5S 2S2, Canada.

9. Arctic Studies Center, P.O. Box 37012, Department of Anthropology, MRC 112, National Museum of Natural History, Smithsonian Institution, Washington, D.C. 20013-7012, USA.

10. Center for Biological Sequence Analysis, Department of Systems Biology, Technical University of Denmark, Kemitorvet, Building 208, room 006, 2800 Kgs. Lyngby, Denmark.

11. AMS 14C Dating Centre, Department of Physics and Astronomy, Aarhus University, Ny Munkegade 120, DK-8000 Aarhus C, Denmark.

12. Anthropological Laboratory, Institute of Forensic Medicine, Faculty of Health Sciences, University of Copenhagen, Frederik V’s Vej 11, 2100 Copenhagen Denmark.

13. Department of Earth System Science, University of California, Irvine, Keck CCAMS Group, B321 Croul Hall, Irvine, California, 92697, USA.

14. Department of Archaeology, Memorial University, Queen's College, 210 Prince Philip Drive, St. John's, Newfoundland, A1C 5S7, Canada.

15. Department of Human Evolution, Max Planck Institute for Evolutionary Anthropology, Deutscher Platz 6, 04103 Leipzig, Germany.

16. Canadian Museum of History, 100 Rue Laurier, Gatineau, Quebec K1A 0M8, Canada.

17. Department of Anthropology, University of Western Ontario, 1151 Richmond St. N., London N6A 5C2, Canada.

18. Leverhulme Centre for Human Evolutionary Studies, Dept. of Archaeology \& Anthropology, University of Cambridge, The Henry Wellcome Building, Fitzwilliam Street, Cambridge CB2 1QH, UK. 19. Department of Archaeology, University of Aberdeen, St. Mary's Building, Elphinstone Road, Aberdeen AB24 3UF, Scotland, UK. 
20. National Museum of Denmark, Frederiksholms kanal 12, DK-1220 Copenhagen, Denmark.

21. Estonian Biocentre, Evolutionary Biology Group, Tartu 51010, Estonia.

22. Department of Evolutionary Biology, University of Tartu, Tartu 51010, Estonia.

23. Department of Genetics, School of Medicine, Stanford University, 300 Pasteur Dr. Lane Bldg Room L331, Stanford, California 94305, USA.

24. School of Biological Sciences, Washington State University, PO Box 644236, Eastlick Hall 395, Pullman, Washington 99164, USA.

25. Department of Integrative Biology, University of California, Berkeley, CA 94720 USA.

26. Ancestry.com DNA LLC, San Francisco, CA 94107, USA.

27. Informatics and Bio-computing, Ontario Institute for Cancer Research, 661 University Avenue, Suite 510, Toronto, Ontario, Canada, M5G 0A3, Canada.

28. Center for Genomic Medicine, Rigshospitalet, University of Copenhagen, Blegdamsvej 9, DK-2100 Copenhagen, Denmark.

29. Institute of Biochemistry and Genetics, Ufa Scientific Center of Russian Academy of Sciences, Ufa Russia.

30. Department of Genetics and Fundamental Medicine, Bashkir State University, Ufa, Bashkortostan, Russia, 450074

31. State Museum for Oriental Art, 12a, Nikitsky Boulevard, Moscow 119019, Russia.

32. Greenland National Museum and Archives, P.O. Box 145, DK-3900 Nuuk, Greenland.

33. Division of Endocrinology, Metabolism and Molecular Medicine, Department of Medicine,

Northwestern University Feinberg School of Medicine, 303 East Chicago Avenue, Tarry, 15-759, Chicago, IL 60611, USA.

34. Department of Anthropology, Weinberg College of Arts and Sciences, Northwestern University. 1810 Hinman Avenue, Evanston, IL 60208, USA.

35. Center for Genetic Medicine, Northwestern University Feinberg School of Medicine, 303 E. Superior Street, Lurie 7-125, Chicago, IL 60611, USA.

36. Department of Anthropology, University of Utah, 270 S. 1400 E., Salt Lake City, UT 84112, USA.

37. Medical-Genetic Center of Russian Academy of Sciences, 10 Naberezhnaya Ushaiki, Tomsk 634050, Russia.

38. Department of Archaeology and Classical Studies, Stockholm University, Stockholm, Sweden.

39. Department of Archaeology and Anthropology, University of Cambridge, The Henry Wellcome Building, Fitzwilliam Street, Cambridge CB2 1QH, UK.

40. Laboratory of Biological Anthropology, University of Kansas, 1415 Jayhawk Blvd., 622 Fraser Hall, Lawrence, Kansas 66045, USA.

$* \quad$ Equal contribution

$\wedge \quad$ Deceased

\# $\quad$ Corresponding author 
The New World Arctic, the last region of the Americas to be populated by humans, has a relatively well-researched archaeology but is lacking an understanding of its genetic history. We present genome-wide sequence data from ancient and present-day humans from Greenland, Arctic Canada, Alaska, Aleutian Islands and Siberia. We show that Paleo-Eskimos (ca. 3000 BC-1300 AD) represent a migration pulse into the Americas independent of both Native American and Inuit expansions. Furthermore, the genetic continuity characterizing the Paleo-Eskimo period was interrupted by the arrival of the ancestors of present-day Inuit, with evidence of gene flow between these populations. Despite periodic abandonment of major Arctic regions, a single Paleo-Eskimo meta-population likely survived in near-isolation for more than 4,000 years, only to vanish around 700 years ago. 
Humans first peopled the North American Arctic (northern Alaska, Canada and Greenland) from the Bering Strait region beginning around 6,000 years before present (1), leaving behind a complex archaeological record [supplementary text S1 (2), Fig. 1A]. Over successive millennia, the pioneering Arctic cultures developed into distinct lifestyles and cultural stages grouped within two broad cultural traditions known as Paleo-Eskimo and Neo-Eskimo. Early Paleo-Eskimo people representing the Denbigh, Pre-Dorset, Independence I and Saqqaq cultures (ca. 3,000-800 BC) lived in tent camps and hunted caribou, musk ox and seals with exquisitely-flaked stone tools similar to those used by northeast Siberian Neolithic cultures (25). In northern Alaska, the Denbigh cultural groups were succeeded by the Paleo-Eskimo Choris and Norton cultures starting around $900 \mathrm{BC}$, with the Norton material culture further developing into the Ipiutak culture around $200 \mathrm{AD}(79,83)$. Simultaneously, during the cold period beginning around $800 \mathrm{BC}$, innovations in housing and hunting technologies accompanied the formation of the Late Paleo-Eskimo or Dorset culture in eastern Arctic (eastern Canadian Arctic and Greenland), with population growth and more intensive use of marine mammals including walrus $(5,6,7)$. The Dorset culture is divided into three phases: (i) Early Dorset ca. 800 BC - 0 BC/AD, (ii) Middle Dorset ca. 0 BC/AD - 600-800 AD, and, (iii) Late Dorset ca. 600-800 $\mathrm{AD}-1300 \mathrm{AD}$ (7). The Paleo-Eskimo tradition in the eastern Arctic ended sometime between 1150-1350 AD; shortly after the sudden appearance of the Neo-Eskimo Thule whale-hunters from the Bering Strait region (7-15).

The Siberian Old Bering Sea culture is the earliest expression of the Neo-Eskimo tradition ca. 2,200 years before present, developing into the Punuk culture around the sixth century AD. Almost concurrently, the Old Bering Sea culture developed into the Birnirk culture in the northern parts of the Bering Strait region. Interactions between people of the Birnirk and Punuk cultures gave rise to the western Thule culture on both sides of the Bering Strait. On the Alaskan side of the Strait, the Ipiutak culture also contributed to the formation of the western Thule culture, (80). By the early second millennium $\mathrm{AD}$, western Thule cultural groups began their movement into the eastern North American Arctic $(12,81)$. With the Thule culture came more effective means of transportation like dog sleds and large skin boats, complex tool kits like sinewbacked bows and harpoon float gear for hunting large whales and sinew-backed bows $(8,16)$. Thule culture spread quickly throughout the eastern Arctic, rapidly replacing Dorset in most, if not all, regions. The decline of whaling during the latter part of the Little Ice Age (sixteenth to nineteenth century AD) resulted in a readjustment to ice-edge and breathing hole hunting of walrus and seal, laying the foundation for modern Inuit cultures (17). Additionally, the Norse (Vikings) formed settlements in Greenland around 985 AD and occupied regions in southern Greenland for about 500 years, contemporaneous with both the Late Dorset and Thule, reaching Newfoundland and Labrador in eastern Canada around 1000 AD (18).

Continuities in chipped stone bifaces and blade and burin technology point to Paleo-Eskimo origins among Siberian Neolithic cultures $(5,8,19,20)$. Genetic evidence suggests that the earliest eastern Arctic PaleoEskimo people represented an independent Siberian migration into the New World $(21,22)$ (Fig. 1C). However, to date we have been unable to identify the likely Siberian ancestral population. Some have argued for origins from an ill-defined 8,000-year-old South Alaska Eskimo-Aleut or Na Dene blade and burin complex (23), but these remain controversial. A recent genetic study is in support of the Early PaleoEskimos, specifically Saqqaq, sharing ancestry with Na Dene Native Americans (Fig. 1C), as part of a threewave peopling model of the Americas consisting of (a) Amerindians, (b) Eskimo-Aleuts and, (c) Saqqaq and $\mathrm{Na}$ Dene (24). Alternate hypotheses on Dorset origins include the Aleutian Islanders (27) and earlier theories of Amerindian cultures in eastern Canada and even further south (17,28-30) (Fig. 1C). Current views favor an in situ origin of Dorset from Canadian Pre-Dorset in northern Hudson Bay $(8,11,31,32)$ (Fig. 1B).

Additionally, whether the individual Early, Middle and Late Dorset phases represent genetic continuity of the same peoples or not remains unresolved (Fig. 1B). The Dorset chronological sequence from the T1 site on Southampton Island, Igloolik, South Baffin, and Labrador in Canada provide evidence of cultural continuity through Early to Late Dorset $(16,17,18,32)$, although regional differences and settlement discontinuities are also common $(34,35,36)$. Significant regional discontinuities and occupation gaps also occur in Greenland (7). It is also debated whether abandoned areas were re-occupied by people from a different genetic background and whether this occurred from a Central Arctic ecological 'core area' or 
regional core areas into which human populations retreated and restructured before expanding again into periodically refurbished marginal zones $(16,31)$. The resolution of these controversies has been hindered by the limited amount of Paleo-Eskimo human material, difficulties in assigning cultural affiliation of some finds (36), and dating uncertainties resulting from the strong marine component in the Arctic diet (7).

\section{Samples and sequence data}

We collected bone, teeth, and hair samples from the field and museums representing 169 ancient human remains from Arctic Siberia, Alaska, Canada and Greenland (Fig. S2, Table S1). These remains have been assigned to one of several ancient Arctic cultures on the basis of typological and/or stratigraphic evidence and, in some cases, radiocarbon dating [supplementary text S1 (2)]. To circumvent drawing conclusions from single genomes (40), we generated mitochondrial DNA (mtDNA) data from 158 and low-coverage whole genome datasets from 26 of the ancient samples (up to 0.3X depth) [supplementary text S3 (2), Tables S7, S9A]. Despite colder temperatures in the Arctic, DNA survival in the ancient samples was surprisingly low, ranging from $\sim 0$ to $3.2 \%$ endogenous content based on the genome sequencing data (Table S7). This low endogenous content may be explained by the remains being largely surface burials that suffered from fluctuating temperatures and humidity, and to subsequent storage conditions at museums.

We also sequenced two high-coverage genomes from present-day North American Native Americans belonging to the Na Dene family (the Dakelh of British Columbia, hereafter referred to as Athabascans), and five unrelated, present-day Greenlandic Inuit $(\mathrm{n}=2)$, Aleutian Islander $(\mathrm{n}=1)$ and Siberian Nivkhs $(\mathrm{n}=2)$ to average depths of 20-40X [supplementary text S3 (2), Table S8]. Only the Aleutian Islander showed evidence of recent European admixture, and was masked for non-Native American ancestry tracts prior to analyses [supplementary text S5 (2)]. Additionally, we radiocarbon dated 27 ancient samples and corrected 25 of the dates for marine reservoir effect to account for the dominant marine component in these individuals' diets ( 15 of these samples are represented in the aforementioned genomic dataset) [supplementary text S2 (2)]. This is critical in the accurate cultural assignment of these individuals, especially in cases where stratigraphic information is inconclusive or contentious [supplementary text S1 (2)].

\section{Origins of Paleo-Eskimos}

Diagnostic mtDNA coding region markers were targeted in the ancient samples to determine their mtDNA haplogroup (hg) affinities. While hgs A, B, C, D and X are among the five founding haplogroups in the Americas, previous studies have shown the near-absence of hgs B, C and X in Paleo-Eskimos and Thule as well as among present-day Inuit ( Saillard et al., 2000; Hayes et al., 2005; Helgason et al. 2006; Gilbert et al. 2007; Gilbert et al. 2008, Raff et al. 2011). We observe mtDNA hg D, specifically the lineage hg D2a, in both Early and Late Paleo-Eskimos, with the majority of the Pre-Dorset/Saqqaq and Middle Dorset samples further classified as hg D2a1 [supplementary text S4 (2), Table S9A]. The absence of biological remains affiliated to the Early Dorset phase precludes genetic testing for this period. Hgs D2a and D2a1 are found in present-day Aleutian Islanders and Siberian Eskimos (42), who are genetically among the closest living populations to the previously sequenced Greenlandic Paleo-Eskimo (Saqqaq) individual that also belonged to hg D2a1 (hereafter, high-coverage Saqqaq) (22). The single Canadian Pre-Dorset sample (XIV-H:168, Rocky Point) was typed to hg D4e (referred to as hg D2 in (42)), which is ancestral to hg D2a, but lacks further phylogenetic resolution due to the low coverage nature of the shotgun data [supplementary text S4 (2)].

Maximum likelihood trees based on nuclear DNA variation place the Middle Dorset, Late Dorset and the Canadian Pre-Dorset individuals as sister groups to the high-coverage Saqqaq individual (Figs. 2A, S9B-D), separately from contemporary Greenlandic Inuit or Native Americans [represented by the South American 
Karitiana (44) and the ancient Clovis Anzick-1 individual (45)]. Similar results were obtained when allowing for admixture between populations with TreeMix (43) (Figs. S9C-D). When the analysis was repeated including the Aleutian Islander, which was masked for European ancestry over $c a .80 \%$ of its genome [supplementary text S5 (2)], the Canadian Pre-Dorset, Middle Dorset and the Late Dorset individuals grouped with the high-coverage Saqqaq; as before (Fig. S10).

Pairwise outgroup $f_{3}$-statistics $(46,47)$ and $D$-statistics $(46,48)$ confirm Early and Late Paleo-Eskimos as being significantly (no overlap at three standard errors for the SNP chip data and at one standard error for the sequencing data) closer to one another than to any of the sampled present-day populations, including those from the Americas and Siberia (Figs. 2B, S11A-D). Furthermore, admixture clustering profiles (49) of the high-coverage Saqqaq and a Dorset individual are near-identical (Fig. S8), with both sharing components with present-day Siberian Chukchi and Greenlandic Inuit and, to a lesser extent, with other Siberians and East Asians (Han). Variations in TreeMix graph topologies occurred with the inclusion of the different ancient samples [supplementary text S5 (2)]; however, the resulting conclusions from these trees are consistent with other analyses. Hence, evidence from mitochondrial as well as nuclear markers suggests that all Paleo-Eskimos, from both Canada and Greenland, represent a continuum of the same single ancestral population (Figs. 1B, C). Present-day populations that are genetically closely related to the Paleo-Eskimos include the Greenlandic Inuit, Aleutian Islanders and far-east Siberians (Figs. 2C, S11E).

We additionally tested the claim that Saqqaq and $\mathrm{Na}$ Dene were part of the same expansion into the Americas (26) by including present-day Athabascans, who represent distinct early branches of Native Americans (45), in the TreeMix (43) analysis. The maximum likelihood tree places the Athabascans as a sister clade to Karitiana and Anzick-1 (Fig. S12A). Similarly, using single nucleotide polymorphism (SNP) chip data from select Old and New World populations, masked for European admixture, we observe that the high-coverage Saqqaq individual forms a clade with the far-east Siberian Koryaks instead of with the Chipewyan, another Na Dene population (26) which groups with the South American Karitiana (Fig. S12B). Outgroup $f_{3}$-statistics $(46,47)$ and $D$-statistics $(46,48)$ show that the high-coverage Saqqaq individual is closer to Greenlandic Inuit than to the Na Dene (Figs. S13A-C). Furthermore, the lack of support placing the Saqqaq closer to the Athabascans than to Karitiana (Fig. S13B) is incompatible with a scenario where Saqqaq and Na Dene share a fraction of their ancestries through a secondary Asian stream (26). Overall, our results support the Paleo-Eskimo migration into the Americas as being separate from that of the Na Dene Native Americans (Fig. 1C).

\section{Genetic affiliations of Neo-Eskimos}

Greenlandic and Canadian Neo-Eskimo Thule, and present-day Greenlandic Inuit form a clade in the maximum likelihood trees (Fig. 3A), even under admixture scenarios generated with TreeMix (43) (Fig. S14A-B). This supports genetic continuity over the last $c a$. 1,000 years between these populations, which is also evident by the shared mtDNA haplogroups (hgs A2a, A2b and D3a2a) between them [supplementary text S4 (2), Table S9A]. Furthermore, outgroup $f_{3}$-statistics $(46,47)$ and $D$-statistics $(46,48)$ demonstrate that both Greenlandic and Canadian Thule are closer to present-day Inuit than to other sampled present-day populations or the high-coverage Saqqaq individual (Figs. 3B-C, S15A-C). These results are in agreement with the archaeological literature which suggests that present-day Greenlandic Inuit are direct descendents of the Thule (2,7,50-52) (Fig. 1C).

We additionally analyzed five ancient individuals dated to the $6^{\text {th }}-7^{\text {th }}$ century $\mathrm{AD}$ and associated with the Siberian Birnirk culture, which is part of the Neo-Eskimo tradition and may be one of the cultural ancestors of the Thule (53-55). Evidence from both mitochondrial typing (hg A2a) (Table S9A) and nuclear markers (Figs. S16A-D) reveal that these individuals are genetically closely related to present-day Greenlandic Inuit, providing the first genetic evidence of an Old World population that was not only a cultural precursor of the Thule, but also either closely related to or a component of the ancestral Inuit gene pool (Fig. 1C). We also reassessed claims of the Sadlermuit population from Southhampton Island in the Hudson Bay region being 
remnants of the Dorset culture on the basis of cultural similarities and mtDNA markers $(56,57)$. We typed ten Sadlermiut individuals, dating to the $15^{\text {th }}-19^{\text {th }}$ century, to mtDNA hgs A2b and D3a2a [supplementary text S4 (2), Tables S9A, S10], which are characteristic of the Thule/Inuit. Also, from their nuclear genome sequences, two of these individuals form a clade with present-day Greenlandic Inuit and not the highcoverage Saqqaq individual (Figs. 3A, S14A). This implies that the Sadlermiut were either genetically derived from or closely related to the Thule, rather than the Paleo-Eskimos (Fig. 1C).

Additionally, whether the Norse admixed with neighbouring Dorset or Thule groups remains debated, even though no anthropological evidence supporting such admixture has been found (58). In order to address this hypothesis, we tested 34 Norse individuals from southern Greenland, across the time span of their occupation in the region, for matrilineal admixture with neighboring Paleo- and Neo-Eskimo populations [supplementary text S1 (2)]. We found no New World-specific mitochondrial markers in these Norse samples, especially the Arctic-specific hgs A and D, suggesting that no detectable matrilineal gene flow occurred from the Dorset or Thule into the sampled Greenlandic Norse [supplementary text S4 (2), Tables S9B-C].

\section{Admixture signals in Paleo- and Neo-Eskimos}

We further investigated the observed genetic affinity between present-day Greenlandic Inuit and PaleoEskimos. $D$-statistics tests $(46,48)$ and outgroup $f_{3}$-statistics $(46)$ support the Paleo-Eskimos as closer to Greenlandic Inuit than to other present-day New World populations (Figs. S13A, S17A-B), with the exception of the Aleutian Islanders whose genetic proximity to the Inuit is evident in analyses from both sequencing data (Fig. S10) and SNP chip data (26) and, Naukan who have been shown to possess EskimoAleut ancestry as a result of back-migration of a related population (26). Maximum likelihood trees with migration edges inferred with TreeMix show evidence for admixture between Paleo-Eskimos and Greenlandic Inuit (Fig. 4A), mediated by the ancient Neo-Eskimos which include the Canadian Thule, the Greenlandic Thule and the Siberian Birnirk (Figs. S9A, S9C-D, S14A-B, S16A). In all the cases, this gene flow event is among the first few migration edges to be inferred by TreeMix (number of migration edges, $m$ $=1-4)$. Bootstrap support suggested that gene flow likely occurred in both directions between the various Paleo- and Neo- Eskimo groups (Table S13).

While evidence for gene flow events was also observed in the high-coverage Saqqaq individual, we wanted to test whether this was due to TreeMix being unable to distinguish between Saqqaq and Dorset due to their genetic similarity and, if admixture might have actually occurred between Dorset and Neo-Eskimos. Therefore, we generated simulated datasets with varying levels of admixture (10\% and 25\%) between Dorset and Inuit in both directions, and determined whether a migration edge was observed in the TreeMix admixture graphs between the high-coverage Saqqaq individual and the Inuit in the absence of the Dorset [supplementary text S5 (2)]. Simulated admixture from Dorset to Inuit was detected by the analysis in the form of gene flow between Saqqaq and Inuit, but the reverse, that is, from Inuit to Dorset through gene flow involving Saqqaq and Inuit, was less likely (Figs. S18A-B, Table S13). Since our data show support for gene flow from the various Neo-Eskimo groups, including present-day Inuit, into the high-coverage Saqqaq individual, it is likely that the admixture involving Saqqaq is not an artifact and occurred from the NeoEskimo lineage into Saqqaq. We cannot, however, exclude the possibility of gene flow also from PaleoEskimos into Neo-Eskimos, or that subsequent gene flow did not occur between the later Dorset phases and the Neo-Eskimo lineage (Table S13).

Since the observed admixture involves the 4,000-year-old Saqqaq individual, it implies that the meeting and intermixing of Paleo-Eskimo and Neo-Eskimo ancestors predates the first archaeological observations of their co-existence in the eastern Arctic by $c a$. 3,000 years or earlier, since Thule groups entered eastern Canada and Greenland, previously occupied by the Late Dorset, only in the $12^{\text {th }}$ or $13^{\text {th }}$ century AD. This also suggests that the admixture is more likely to have occurred either in the Old World prior to the entry of the Neo-Eskimos into the Americas, or in Beringia, but not further east in the New World since no 
archaeological evidence of a parallel existence of Paleo- and Neo-Eskimos around 4,000 years ago or earlier has been documented in this region (Fig. 1C).

We also investigated the level of genetic contribution from the $\sim 24,000$-year-old Siberian boy from Mal'ta (MA-1) (47) into Paleo-Eskimos and Greenlandic Inuit. Pairwise outgroup $f_{3}$-statistics tests indicate that sampled western Eurasians and MA-1 are slightly closer to the high-coverage Saqqaq than to the Han Chinese (47) (Figs. 4B, S19). To confirm that this genetic affinity between Saqqaq and MA-1 was not due to ancient DNA bias, we also included the $~ 7,000$-year-old La Brana 1 sample from Spain (59) in our analysis and found that it clustered close to present-day Europeans, hence confirming that our results were not skewed by ancient DNA attraction (Fig. 4B). TreeMix predicts a gene flow event from the high-coverage Saqqaq into MA-1 and vice-versa, consistent with (60), but with low support to substantiate both this signal and the inferred direction [Fig. 4C, Table S13, supplementary text S5 (2)].

In contrast, gene flow from MA-1 into the root of the clade comprising Native American populations (Karitiana and Anzick-1) and including the Greenlandic Inuit is detected with high bootstrap support, in agreement with (47) (Figs. 1B, 4C, Table S13). Additionally, $D$-statistics (46) and outgroup $f_{3}$-statistics $(46,47)$ from SNP chip data show that MA-1 is significantly (no overlap at three standard errors) closer to the Chipewyan than to the high-coverage Saqqaq (Fig. S20), which is compatible with other results presented in this study that also reject a single wave model for Saqqaq and $\mathrm{Na}$ Dene. Overall, while there is evidence of genetic affinity between MA-1 and Saqqaq, we are unable to ascertain whether this is due to gene flow or shared ancestry between the two lineages. It is also possible that this affinity is a consequence of the aforementioned gene flow from Neo-Eskimos, who received MA-1 gene flow, into the Saqqaq lineage.

\section{Discussion}

We overcome the difficulties of studying the peopling of the Arctic by including an extensive collection of Paleo-Eskimo remains for both ancient DNA and radiocarbon analyses. We have shown that Paleo-Eskimos likely represent a single migration pulse into North America from Siberia; separate from the migration events giving rise to Native Americans and Inuit. However, while being genetically distinct from other New World populations, Paleo-Eskimos are still more closely related to these populations than to non-New World populations, which supports the Beringian Standstill model (Tamm et al.) stating that a single ancestral population gave rise to many sub-populations, and possibly many migration pulses. Moreover, while our data are in agreement with Reich et al. (26), we find no support for Saqqaq or the rest of the Paleo-Eskimo tradition being a part of one of the two waves of Native American ancestors entering the more southern regions of the Americas. Therefore, an additional Paleo-Eskimo migration wave should be added to the three-wave hypothesis in explaining the peopling of the Americas (26).

Furthermore, Paleo-Eskimo and Inuit peoples appear to have occupied the New World Arctic for more than 4,000 years, with only a single population replacement (Thule) less than 700 years ago. In contrast with the dynamic responses of the Thule people to climate change $(19,61,62)$, Siberian iron trade (64) and Norse contact (14), the 4,000-year Paleo-Eskimo period presents a single tradition of continuous technological and social development, including geographical dislocations and periods of relative stability punctuated by episodes of rapid change (16). The long-term continuity of the Paleo-Eskimo population and its culture is especially striking given the climatic and ecological cycles over 4,000 years - from warm late hypsithermal to cold sub-boreal through the early medieval warm event, as well as changes in sea ice distribution, changes in animal population cycles and distribution (11). In light of this, Paleo-Eskimo survival must be due to a remarkable resilience among small, dispersed local groups with the ability to shift their small population units to new areas when their homes became untenable; like the complete de-population of Greenland and the abandonment of the Canadian High Arctic between $c a .1-700$ AD (7). Such events argue for the reformulation of the original 'core area' hypothesis to a network of regional 'core areas' that served as demographic reservoirs for repopulating areas abandoned due to climate change, animal population crashes, or human over-hunting. 
This paper also contributes to the long-standing debate about the Dorset-Thule transition. Dorset harpoons, snow knives, snow houses, soapstone vessels and Dorset art in Thule sites are considered evidence of sustained contact and acculturation (McGhee 2000, 2009; Fitzhugh 2004; Friesen 2004; Friesen and Arnold 2008, Sutherland 2009; Appelt and Gulløv 2009). The re-dating of the Thule migration to $c a .1300$ AD, coincident with the latest Dorset radiocarbon dates, reduces the possibility for contact and exchange and strengthens the case for isolation (Park 1993, 2000). However, despite our results showing evidence of early contact and admixture between the Paleo-Eskimo and Neo-Eskimo lineages, dating to at least ca. 4,000 years ago, we cannot preclude a scenario where subsequent gene flow might also have occurred between Late Dorset and Thule groups. A related result of this study is the Thule affiliation of the Sadlermiut individuals. This culture that went extinct in 1903 from European disease has long been considered Thule-acculturated Dorset people (Collins 1958; deLaguna 1947; Thomson 1988); genetic evidence now suggests they were Thule people who had somehow acquired Dorset stone technology (Park 1993; Rowley 1994). If Dorset and Thule overlapped chronologically and geographically, as it appears they did at least in some areas, what social mechanisms resulted in genetic isolation? So far, there is no evidence of massacres, although the spread of Norse diseases have been suggested (Agger and Maschner 2009). Similar questions can be raised with regard to lack of matrilineal gene flow between the Thule or Dorset and the Greenland Norse (Appelt and Gulløv 2009).

Our study contrasts with previous population-level genetic studies, such as those focusing on the introduction of agriculture in Europe (Neolithization), which found that population movements were the instigators of changes in culture and subsistence strategies (60,65-67). Paleo-Eskimo technological innovations seem to have occurred solely by movement of ideas within a single resident population. Hence, our findings suggest that caution is required when using cultural similarities and differences as proxies for population movements and migrations into new and dramatically different environments (36).

\section{Methods}

DNA from 169 ancient human bone, teeth and hair samples from Arctic Siberia, Alaska, Canada and Greenland was extracted and targeted for haplogroup diagnostic mitochondrial DNA markers, while a subset of 26 samples was converted into Illumina libraries and sequenced, using standard laboratory procedures [supplementary text S3 (2)]. Two present-day Greenlandic Inuit, two Nivkhs, one Aleutian Islander and two Athabascans were genome sequenced with no objections from The National Committee on Health Research Ethics, Denmark (H-3-2012-FSP21) [supplementary text S2 (2)]. 27 samples were radiocarbon dated and corrected for marine reservoir offset [supplementary text S2 (2)]. Mitochondrial DNA contamination estimates were computed as noted in supplementary text S4 (2). Error rate analysis, ancient DNA damage analysis, multidimensional scaling analysis on SNP chip and sequencing data, NGSadmix analysis, ABBABABA tests on sequencing data, $D$-statistics and $f_{3}$-statistics tests on SNP chip and sequencing data, TreeMix analysis on SNP chip and sequencing data, neighbor-joining analysis, and, ancestry painting of the Aleutian genome were performed as described in supplementary text S5 (2).

\section{Acknowledgements}

We thank the Danish National Sequencing Centre, T. B. Brand and P. S. Olsen for technical assistance, anonymous donors for providing DNA samples, A. Helgason and S. Sunna Ebenesersdóttir from deCODE for their input on mtDNA phylogenies, A, Di Rienzo for access to genotyping data from Siberian populations, J. R. Southon (BTF), Kitikmeot Heritage Society (TMF), Polar Continental Shelf Project (TMF), Inuit Heritage Trust (DHO'R, JeC, JoC, MGH), Kivalliq Inuit Association (DHO'R, JoC, MGH), communities of Coral Harbor and Chesterfield Inlet (DHO'R, JoC, MGH), Canadian Museum of History (DHO'R, JeC, JoC, MGH), D. Morrison (DHO'R, JeC, JoC, MGH), L. Wood (DHO'R, JoC, MGH), J. Young (DHO’R, JeC, JoC, MGH), D. Stenton (DHO'R, JeC, JoC, MGH), S. Girling-Christie (JeC), 
Commission for Scientific Research in Greenland (JA), Greenland National Museum \& Archives (JA), Parks Canada (MAPR, VG), Memorial University (VG, MAPR), Government of Newfoundland and Labrador (VG), The Rooms Inc. (VG), Innu Nation (VG), Nunatsiavut Government (VG), Miawpukek First Nation (VG), D. Lavers (VG), R. Anstey (VG), W. Jones and Qanirtuuq Inc., Quinhagak, Alaska (KB and RK), the residents of Quinhagak, Alaska (KB and RK), NIMA Corporation, Mekoryuk, Alaska (KB and RK), and the Carnegie Trust for the Universities of Scotland (KB and RK). Supported by the Danish National Research Foundation (EW) Lundbeck Foundation (EW, NL), Villum Foundation (AA), SNSF Fellowship (AS-M, PBSKP3_143259), The Rock Foundation (BG, MA), Social Sciences and Humanities Research Council of Canada (TMF), National Science Foundation Office of Polar Programs (DHO'R: OPP-9974623 and OPP0327641; JoC: OPP-9726126 and OPP-9977931; MGH: OPP-9813044), Northern Worlds Initiative (HCG), Augustinus Foundation (HCG), the Danish Council for Independent Research (IM), National Science Foundation (JA: IPY grant 0732327; MHC, OPP-9905090 and OPP-0327676), Wenner-Gren Foundation for Anthropological Research (MGH: No. 6364), Natural Sciences and Engineering Research Council of Canada Postgraduate Fellowship (MGH), University of Utah Graduate Research Fellowship (MGH), EU Marie Curie FP7 Initial Training Network Grant (MaR: FP7-ITN-215362-2), Arts and Humanities Research Council (KB and RK: AH/K006029/1), Memorial University Faculty of Arts Research Initiative (VG), Memorial University Office of Research Grant (VG), Social Sciences and Humanities Research Council of Canada (MAPR), EU European Regional Development Fund through the Centre of Excellence in Genomics to Estonian Biocentre (MM and RV), Estonian Institutional Research (MM and RV: grant IUT24-1), and, Estonian Science Foundation (MM and RV: grant 8973. Informed consent was obtained for the genome sequencing of the modern individuals, with ethical approval from The National Committee on Health Research Ethics, Denmark (H-3-2012-FSP21). Sequence data for the ancient samples are available for download through European Nucleotide Archive (ENA) accession number XYZ, while those for the modern populations are available for demographic research under data access agreement with EW. The authors declare no competing financial interests.

\section{Figure legends}

Figure 1. Chronology, origins and continuity of Paleo-Eskimos and Neo-Eskimos. Support from genetic results presented in this study is indicated by '(S)' and rejection by '(R)'. A) A chronological framework for the prehistoric cultures in the New World Arctic and northeast Siberia, based on a combination of screened radiocarbon dates of associated terrestrial materials, typological studies, and contexts (eg.

$7,31,32,35,79,84,85)$. Fading colors symbolize uncertainties concerning the beginnings or ends of the archaeological cultures, due to plateaus or wiggles in the radiocarbon calibration curve or lack of data. Defined archaeological phases within a culture are separated by a white line. Dark reddish-brown towards the top of the figure indicates historical times. Cultural contexts from which samples included in this study arise are highlighted in yellow. B) A two-wave migration model into the New World Arctic, with continuity throughout the Paleo-Eskimo tradition, followed by the Neo-Eskimo migration, is supported. Black thunderbolt symbols represent genetic discontinuity. C) This schematic summarizes the proposed origins of Paleo- and Neo-Eskimos in the archaeological and genetic literature and their relationships with other ancient populations in the North American Arctic. Our data shows support for Paleo-Eskimos constituting a migration pulse into the Americas independent to those of other New World populations (scenario 1) (2,2123). For reference, we show the maximal geographical distribution of the Paleo-Eskimos and Neo-Eskimos in the New World Arctic and far-east Siberia (7). Additionally, plotted are Paleo-Eskimo (Pre-Dorset, Saqqaq, Dorset), Thule, Birnirk and Norse sites from which samples in this study derive; for further information see Fig. S2 and Table S1.

Figure 2. Origins of Paleo-Eskimos and genetic continuity. A) Sequencing data-based maximum likelihood trees constructed with TreeMix (43) with the high-coverage Saqqaq (23), Middle Dorset and Late Dorset datasets, and 17 present-day and two ancient populations; for Greenlandic Inuit see supplementary text S5 (2). The scale bar represents ten times the average standard error (s.e.) of the values in the covariance matrix. 
Residual matrices are shown in Figs. S9C-D. B) SNP chip data-based $D$-statistic tests of the form $D$ (Yoruba, Dorset; X, Saqqaq), where X represents present-day American and Siberian populations from (26) (coloured centers represent populations divided by linguistic affiliation, see legend at bottom). Thick and thin lines represent one and three standard errors of the $D$-statistics, respectively. Middle and Late Dorset (left and right panels, respectively) are significantly (no overlap at three standard errors) closer to Saqqaq than to the sampled present-day populations. C) Heat map of the SNP chip data-based statistic $f_{3}$ (Yoruba; Saqqaq, X), where $X$ represents present-day worldwide non-African populations. The graded heat key (to the right of the image) represents the magnitude of the computed $f_{3}$-statistics.

Figure 3. Genetic affinities of the Neo-Eskimo Thule. A) Sequencing data-based maximum likelihood trees constructed with TreeMix (43) with the high-coverage Saqqaq (23), Canadian Thule and Greenlandic Thule datasets, and 17 present-day and two ancient populations. The scale bar represents ten times the average standard error (s.e.) of the values in the covariance matrix. Residual matrices are shown in Figure S14A-B. B) SNP chip data-based $D$-statistic tests of the form $D$ (Yoruba, Thule; X, West Greenlanders), as in Fig. 2. Canadian and Greenlandic Thule (left and right panels, respectively) are significantly (no overlap at three standard errors) closer to present-day West Greenlandic Inuit than to other worldwide present-day populations. Similar results are observed with East Greenlandic Inuit in place of West Greenlandic Inuit (Fig. S15C). C) Heat maps of the SNP chip data-based statistic $f_{3}$ (Yoruba; Thule, X), as in Fig. 2.

Figure 4. Admixture signals in Paleo-Eskimos and Greenlandic Inuit. A) Admixture graph (number of migration edges, $m=3$ ) constructed with TreeMix (43), with the high-coverage Saqqaq (23), 17 present-day and two other ancient individuals. The scale bar represents ten times the average standard error (s.e.) of the values in the covariance matrix, and the migration weight represents the fraction of ancestry derived from the migration edge. Migration edges are observed between the Paleo-Eskimos and Greenlandic Inuit, shown here as gene flow from the high-coverage Saqqaq to the root of East and West Greenlandic Inuit, although gene flow in the other direction is also observed (Table S13). Admixture graphs with other Paleo-Eskimo and Neo-Eskimo populations, different numbers of migration edges and, residual matrices are shown in Figs. S9A-D, S14A-B and S16A. B) Biplot of SNP chip data-based statistic $f_{3}$ (Yoruba; Saqqaq, X) versus $f_{3}($ Yoruba; Han, $\mathrm{X})$, where $\mathrm{X}$ represents present-day worldwide non-African populations. Thick and thin errors bars represent one and three standard errors of the $f_{3}$-statistics, respectively. Western Eurasian populations (Europeans and, South and Central Asians) are shifted towards the high-coverage Saqqaq compared to the Han Chinese. La Brana was included in the analysis to evaluate potential ancient DNA bias between the Saqqaq and MA-1 datasets. C) Sequencing data-based admixture graph with 17 present-day and four ancient individuals. A known migration edge is inferred from MA-1 to the root of Native Americans and Inuit, but this gene flow event excludes the high-coverage Saqqaq individual. Admixture graphs with different number of migration edges and residual matrices are shown in Fig. S21, and bootstrapping results are shown in Table S12. See supplementary text S5 (2) regarding the migration edge from Saqqaq into MA1 . 


\section{References}

1. R. K. Harritt, Paleo-Eskimo beginnings in North America: a new discovery at Kuzitrin Lake, Alaska. Etudes Inuit 22, 61-81 (1998).

2. H. B. Collins, in Prehistoric cultural relations between the arctic and temperate zones of North America, J. M. Campbell, Ed. (Arctic Institute of North America, Montreal, 1962), pp. 126-139.

3. N. N. Dikov, Early Cultures of Northeast Asia (U.S. Department of the Interior, Shared Beringian Heritage Program, National Park Service, Anchorage, Alaska, 1979).

4. D. E. Dumond, The Eskimos and Aleuts (Thames and Hudson, London, 1977).

5. J. Dixon, Arrows and Atl Atls: Guide to the Archaeology of Beringia (National Park Service, Washington D.C., 2013).

6. M. S. Maxwell, in Arctic, D. Damas, Ed. (Smithsonian Institution, Washington, D.C., 1984).

7. B. Grønnow, M. Sørensen, in Dynamics of Northern Societies, J. Arneborg, B. Grønnow, Eds. (National Museum of Denmark, Copenhagen, 2006), pp. 59-74.

8. R. McGhee, Ancient People of the Arctic (UBC Press, Vancouver, 1996).

9. M. Appelt, B. Gulløv, Eds., Late Dorset in High Arctic Greenland (Danish Polar Center, Danish National Museum, Copenhagen, 1999).

10. R. W. Park, The Dorset-Thule Succession in Arctic North America: Assessing Claims for Culture Contact. American Antiquity 58, 203-234 (1993).

11. W. W. Fitzhugh, in Encyclopedia of Archaeology, D. M. Pearsall, Ed. (Academic Press, New York, 2008), pp. 247-271.

12. M. T. Friesen, C. D. Arnold, The Timing of the Thule Migration: New Dates from the Western Canadian Arctic. American Antiquity 73, 527-538 (2008).

13. R. E. Hollinger, R. Eric, S. Ousley, C. Utermohle, in The Northern World AD 900-1400, H. Maschner, O. Mason, R. McGhee, Eds. (University of Utah Press, Salt Lake City, 2009), pp. 131-154.

14. R. McGhee, in The Northern World AD 900-1400, H. Maschner, O. Mason, R. McGhee, Eds. (University of Utah Press, Salt Lake City, 2009), pp. 155-163.

15. D. Morrison, in The Northern World AD 900-1400, H. Maschner, O. Mason, R. McGhee, Eds. (University of Utah Press, Salt Lake City, 2009), pp. 164-178.

16. M. Maxwell, Prehistory of the Eastern Arctic. (Academic Press, Orlando, 1985).

17. R. McGhee, in Handbook of North American Indians, D. Damas, Ed. (Smithsonian Institution, Washington, D.C., 1984), pp. 369-376.

18. W. W. Fitzhugh, E. I. Ward, Eds. Vikings: the North Atlantic Saga (Smithsonian Institution Press, Washington, D.C., 2000). 
19. R. Powers, R. H. Jordan, Human biogeography and climate change in Siberia and Arctic North America in the Fourth and Fifth Millennia B.P. Phil. Trans. of the Royal Society of London A330, 665-670 (1990).

20. W. N. Irving, The Arctic Small Tool Tradition. Proceedings of the 8th International Congress of Anthr. And Ethn. Sciences 3, 340-342 (1969-1970).

21. M. T. Gilbert et al., Paleo-Eskimo mtDNA genome reveals matrilineal discontinuity in Greenland. Science 320, 1787-1789 (2008).

22. M. Rasmussen et al., Ancient human genome sequence of an extinct Palaeo-Eskimo. Nature 463, 757762 (2010).

23. W. S. Laughlin, Aleuts: ecosystem, Holocene history, and Siberian origin. Science 189, 507-515 (1975).

24. D. Reich et al., Reconstructing Native American population history. Nature 488, 370-374 (2012).

27. T. L. Black, Aleut Art: Unangam Aguqaadangin (Aleutian/Pribilof Islands Association, Anchorage, 2003).

28. F. deLaguna, in Man in Northeastern North America. F. Johnson, Ed. (Phillips Academy, Andover, 1946), pp.106-142.

29. W. A. Ritchie, in Prehistoric cultural relations between the arctic and temperate zones of North America, J. M. Campbell, Ed. (Arctic Institute of North America, Montreal, 1962), pp. 96-99.

30. H. B. Collins, Archaeological Investigations on Southampton and Walrus Islands, N.W. National Museum of Canada Bulletin 147, 22-61 (1958).

31. J. M. Savelle, A. S. Dyke, Paleoeskimo occupation history of Foxe Basin, Arctic Canada: Implications for the core area model and Dorset origins. American Antiquity 79, 249-276 (2014).

32. J. A. Tuck, W. Fitzhugh, In Palaeo-Eskimo cultures in Newfoundland, Labrador and Ungava (Memorial University of Newfoundland, St. John's, 1986) pp. 161-167.

31. P. Desrosiers, thesis, Université Paris 1 Panthéon-Sorbonne (2009).

32. A.S. Dyke, J.M. Savelle, D.S. Johnson, Paleoeskimo Demography and Holocene Sea-Level History, Golf of Boothia, Arctic Canada. Arctic 64, 151-168 (2011).

33. J. M. Savelle, A. S. Dyke, M. Poupart, in The Northern World AD 900-1400, H. Maschner, M. Owen, R. McGhee, Eds. (The University of Utah Press, Salt Lake City, 2009), pp. 209-234.

34. E. Harp, The cultural affinities of the Newfoundland Dorset Eskimos (National Museum of Canada, Ottawa, 1964).

35. M. A. P. Renouf, Ed., The cultural landscapes of Port aux Choix (Springer, New York, 2011).

36. W. W. Fitzhugh, Biogeographical Archeology in the Eastern North American Arctic. Human Ecology 25, 385-418 (1997).

37. D. Odess, The archaeology of interaction: views from artifact style and material exchange in Dorset society. American Antiquity 63, 417-435 (1998). 
38. R. McGhee, in Eastern Arctic Prehistory: Paleoeskimo Problems, M. Maxwell, Ed. (Society for American Archaeology, Washington, D.C., 1976), pp. 15-39.

39. W. W. Fitzhugh, in Eastern Arctic Prehistory: Paleoeskimo Problems, M. Maxwell, Ed. (Society for American Archaeology, Washington, D.C., 1976), pp. 139-149.

40. J. K. Pickrell, D. Reich, Towards a new history and geography of human genes informed by ancient DNA. bioRxiv (2014), doi: 10.1101/003517.

41. A. W. Briggs et al., Patterns of damage in genomic DNA sequences from a Neandertal. Proc. Natl. Acad. Sci. 104, 14616-14621 (2007).

42. N. V. Volodko et al., Mitochondrial genome diversity in arctic Siberians, with particular reference to the evolutionary history of Beringia and Pleistocenic peopling of the Americas. Am. J. Hum. Genet. 82, 1084$1100(2008)$.

43. J. K. Pickrell, J. K. Pritchard, Inference of population splits and mixtures from genome-wide allele frequency data. PLoS Genetics 8, e1002967 (2012).

44. M. Meyer et al., A High-Coverage Genome Sequence from an Archaic Denisovan Individual. Science 338, 222-226 (2012).

45. M. Rasmussen et al., The genome of a late Pleistocene human from a Clovis burial site in western Montana. Nature 506, 225-229 (2014).

46. N. Patterson et al., Ancient admixture in human history. Genetics 192, 1065-1093 (2012).

47. Raghavan, M. et al., Upper Palaeolithic Siberian genome reveals dual ancestry of Native Americans. Nature 505, 87-91 (2014).

48. R. E. Green et al., A draft sequence of the Neandertal genome. Science 328, 710-722 (2010).

49. L. Skotte, T. S. Korneliussen, A. Albrechtsen, Estimating Individual Admixture Proportions from Next Generation Sequencing Data. Genetics 195, 693-702 (2013).

50. H. B. Collins, Excavations at Thule Culture Sites Near Resolute Bay, Cornwallis Island, N.W.T. National Museum of Canada Bulletin 123, 49-63 (1951).

51. R. H. Jordan, in Handbook of North American Indians, D. Damas, Ed. (Smithsonian Institute, Washington, D.C., 1984), pp. 540-548.

52. J. Meldgaard, in Danish-Netherlands symposium on developments in Greenlandic Arctic culture, H. P. Kylstra, Ed. (University of Groningen, Groningen, 1976), pp. 19-52.

53. T. Mathiassen, Eskimo migrations in Greenland. Geographical Review 25, 408-422 (1935).

54. J. A. Ford, Eskimo prehistory in the vicinity of Point Barrow, Alaska (American Museum of Natural History, New York,1959), pp. 19-21.

55. W. E. Taylor, Hypotheses on the origin of Canadian Thule culture. American Antiquity 28, 456-464 (1963). 
56. M. G. Hayes, J. B. Coltrain, D. H. O'Rourke, in Contributions to the Study of the Dorset Palaeo-Eskimos, P. D. Sutherland, Ed. (Canadian Museum of Civilization, Hull, 2005), pp. 11-32.

57. H. B. Collins, The T1 site at Native Point, Southampton Island, N.W.T. University of Alaska Anthropological Papers 4, 63-89 (1956).

58. N. Lynnerup, The Greenland Norse: A biological-anthropology study, H. C. Gulløv, Ed. (Commission for Scientific Research in Greenland, Copenhagen, 1998).

59. I. Olalde et al., Derived immune and ancestral pigmentation alleles in a 7,000-year-old Mesolithic European. Nature 507, 225-228 (2014).

60. P. Skoglund et al., Science, (10.1126/science.1253448).

61. R. McGhee, Speculations on climate change and Thule culture development. Folk 11-12, 173-184 (19691970).

62. A. McCartney, Thule Eskimo prehistory along northwestern Hudson Bay, (National Museum of Man, Ottawa, 1977).

63. O. K. Mason, in The Northern World AD 900-1400, H. Maschner, O. Mason, R. McGhee, Eds.

(University of Utah Press, Salt Lake City, 2009), pp. 76-128.

64. R. McGhee, The last imaginary place: a human history of the arctic world. (Oxford University Press, Oxford, 2005).

65. H. Malmström et al., Ancient DNA Reveals Lack of Continuity between Neolithic Hunter-Gatherers and Contemporary Scandinavians. Current Biology 19, 1758-1762 (2009).

66. W. Haak et al., Ancient DNA from European Early Neolithic Farmers Reveals Their Near Eastern Affinities. PLoS Biology 8, e1000536 (2010).

67. P. Skoglund et al., Origins and genetic legacy of Neolithic farmers and hunter-gatherers in Europe. Science 336, 466-469 (2012).

68. C. Beck, G. T. Jones, Clovis and Western Stemmed: Population Migration and the Meeting of Two Technologies in the Intermountain West. American Antiquity 75, 81-116 (2010).

69. D. L. Jenkins et al., Clovis Age Western Stemmed Projectile Points and Human Coprolites at the Paisley Caves. Science 337, 223-228 (2012).

70. J. Morrow, T. Morrow, Geographic variation in fluted projectile points: a hemispheric perspective. American Antiquity 64, 215-230 (1999).

71. H. B. Collins, Archaeological Work on Southampton and Walrus Islands, Hudson Bay. Yearbook of the American Philosophical Society 1955, 341-344 (1955).

72.

73. D. J. Stanford, B. A. Bradley, Across Atlantic Ice: The Origins of America's Clovis Culture (University of California Press, Berkeley, 2012).

74. T. Goebel, M. Waters, D.H. O'Rourke, The Late Pleistocene Dispersal of Modern Humans in the Americas. Science 319,1497-1502 (2008). 
75. D. J. Meltzer, First Peoples in a New World: Colonizing Ice Age America (University of California Press, Berkeley, 2009).

76. M. M. Bronštein, in Arktische Waljäger vor 3000 Jahren. Unbekannte sibirische Kunst, A. M. Leskov, H. Müller-Beck (Hase \& Koehler Verlag, 1993), pp. 73-84.

77. O. K. Mason, in Identities and Cultural Contacts in the Arctic, M. Appelt, J. Berglund, H.C. Gulløv, Eds. (The National Museum of Denmark, Copenhagen, 2000), pp. 229-251.

78. R. Blumer, in Archaeology in the Bering Strait Region, D. E. Dumond, R. L. Bland, Eds. (University of Oregon, 2002), pp. 61-106.

79. E. J. Dixon, Arrows and Atl Atls: A Guide to the Archaeology of Beringia (National Park Service, 2013).

80. O. K. Mason, in An Ipiutak Outlier: A 1,500-Year Old Qarigi at Qitchauvik on The Golovin Lagoon, O. K. Mason, M. A. Sweeney, C. Alix, V. Barber, Eds. (National Park Service, Alaska Region, 2007), pp. 1622.

81. D. Morrison, The Earliest Thule Migration. Canadian Journal of Archaeology 22, 139-156 (1999).

82. D. Slaughter, Radiocarbon Dating the Arctic Small Tool tradition in Alaska. Alaska Journal of Anthropology 3,117-134 (2005).

83. S. L. Anderson, A. K. Freeburg, A High-Resolution Chronology for the Cape Krusenstern Site Complex, Northwest Alaska. Arctic Anthropology, 50, 49-71 (2013).

84. J. F. Jensen, in Dynamics of Northern Societies, J. Arneborg, B. Grønnow, Eds. (National Museum of Denmark, Copenhagen, 2006), pp. 75-86.

85. P. Schledermann, Crossroads to Greenland: 3000 Years of Prehistory in the Eastern High Arctic (University of Calgary, Calgary, 1990)

86. A. S. Dyke, J. M. Savelle, Paleoeskimo Demography and Sea-Level History, Kent Peninsula and King William Island, Central Northwest Passage, Arctic Canada. Arctic 62, 371-392 (2009).

87. J. M. Savelle, A. S. Dyke, Variability in Paleoeskimo Occupation on South-Western Victoria Island, Arctic Canada: Causes and Consequences. World Archaeology 33, 508-522 (2002).

88. J. M. Savelle, A. S. Dyke, Paleoeskimo demography on western Boothia Peninsula, Arctic Canada. Journal of Field Archaeology, 34, 267-283 (2009).

89. T. M. Friesen, in The Northern World AD 900 - 1400, H. Maschner, O. K. Mason, R. McGhee, (The University of Utah Press, 2009), pp. 235-248.

90. R. Park, in Identities and Cultural Contacts in the Arctic, M. Appelt, J. Berglund, H. C. Gulløv, Eds. (National Museum of Denmark, Copenhagen, 2000), pp. 192-205.

91. M. Appelt, H. C. Gulløv, in in The Northern World AD 900 - 1400, H. Maschner, O. K. Mason, R. McGhee, (The University of Utah Press, 2009), pp. 300-320.

92. P. J. Reimer et al., Intcal04 Terrestrial Radiocarbon Age Calibration, 0-26 Cal Kyr BP. Radiocarbon 46, 1029-1058 (2004). 
93. M. Nagy, Paleoeskimo Cultural Transition: A Case Study from Ivujivik, eastern Arctic (Institut culturel Avataq, 2000).

94. C. Houmard, thesis, l’Université Paris Ouest Nanterre (2011).

95. M. Sørensen, Technology and Tradition in the Eastern Arctic, 2500 BC - AD 1200. (Museum Tusculanum Press, 2012).

96. G. W. Rowley, The Dorset Culture of the Eastern Arctic. American Anthropologist 42, 490-499 (1940).

97. M. S. Murray, The Long-Term Effects of Short-Term Prosperity - An Example from the Canadian Arctic. World Archaeology 30, 466-483 (1999).

98. W. W. Fitzhugh, in Honoring our Elders: A History of Eastern Arctic Archaeology, W. W. Fitzhugh, S. Loring, D. Odess, Eds. (National Museum of Natural History Smithsonian Institution, Washington D.C., 2002), pp. 133-162.

99. B. C. Hood, Towards an Archaeology of the Nain Region (National Museum of Natural History Smithsonian Institution, Washington D.C., 2008).

100. J. W. Helmer, The Palaeo-Eskimo Prehistory of the North Devon Lowlands. Arctic 44, 301-317 (1991).

101. J. W. Helmer, B. V. Kennedy, Early Paleo-Eskimo Skeletal Remains from North Devon Island, High Arctic Canada. Canadian Journal of Archaeology 10, 127-143 (1986).

102. B. Grønnow, in Threads of Arctic Prehistory: Papers in honour of William E. Taylor, Jr, D. Morrison, J-L. Pilon, Eds. (Canadian Museum of Civilization, Gatineau, 1994). pp. 197-238.

103. A. Koch et al. in The Paleo-Eskimo Cultures of Greenland: New Perspectives in Greenlandic Archaeology. B. Grønnow, J. Pind, Eds. (Danish Polar Center, Copenhagen, 1996) pp. 35-38.

104. M. Meldgaard, Ancient Harp Seal Hunters of Disko Bay: Subsistence and Settlement at the Saqqaq Culture Site Qeqertasussuk (2400-1400 BC), West Greenland. (Danish Polar Center, Copenhagen, 2004).

105. J. Meldgaard, Saqqaq-folket ved Itivnera. Nationalmuseets undersøgelser i sommeren 1960. Tidsskriftet Grønland 1, 15-23 (1961).

106. W. E. Taylor, Jr., Summary of Archaeological Field Work on Banks and Victoria Islands, Arctic Canada, 1965. Arctic Anthropology, IV, 221-244 (1967).

107. W. E. Taylor, Jr., An Archaeological Survey Between Cape Parry and Cambridge Bay, N.W.T., Canada in 1963 (National Museum of Canada, Ottawa, 1972).

108. J. Meldgaard, Origin and evolution of Eskimo culture in the eastern Arctic, Canadian Geographical Journal 60, 64-75 (1960).

109. U. Odgaard, in Northern Worlds - Challenges and solutions, H. C. Gulløv, P. A. Toft, C. P. Hansgaard, Eds. (The National Museum of Denmark, Copenhagen, 2011), pp. 247-260.

110. N. Lynnerup et al. Human Dorset Remains from Igloolik, Canada. Arctic, 56, 349-358 (2003).

111. W. E. Taylor, Jr., The Arnapik and Tyara Sites: An Archaeological Study of Dorset Culture Origins (Society for American Archaeology, Salt Lake City, 1968). 
112. P. Desrosiers, D. Gendron, N. Rahmani, in Dynamics of Northern Societies, J. Arneborg, B. Grønnow, Eds. (National Museum of Denmark, Copenhagen, 2006), pp. 131-144.

113. R. H. Jordan, in Palaeo-Eskimo Cultures in Newfoundland, Labrador and Ungava (Reports in Archaeology, St. John's, 1986), pp. 135-150.

114. M. A. P. Renouf, A Review of Palaeoeskimo Dwelling Structures in Newfoundland and Labrador. Études Inuit Studies 27, 375-416 (2003).

115. E. J. Harp, Jr., Late Dorset Eskimo Art from Newfoundland, Folk 11-12, 109-124 (1969/1970).

116. E. J. Harp, Jr., Dorset Settlement Patterns in Newfoundland and Southeastern Hudson Bay (Society for American Archaeology, 1976), pp. 119-138.

117. U. Linnamae, The Dorset Culture, A Comparative Study in Newfoundland and the Arctic. (Newfoundland Museum, St. John's, 1975).

118. S. L. Cox, Paleo-Eskimo occupations of the north Labrador coast. Arctic Anthropology 15, 96-118 (1978).

119. W. W. Fitzhugh, A Review of Paleo-Eskimo Culture History in Southern Quebec-Labrador and Newfoundland. Études Inuit Studies 4, 21-31 (1980).

120. D. T. Robbins, in Palaeo-Eskimo Cultures in Newfoundland, Labrador and Ungava, Report in Archaeology. (Memorial University of Newfoundland, St. John's, 1986) pp. 119-124.

121. E. J. Harp, D. R. Hughes, Five Prehistoric Burials from Port Aux Choix, Newfoundland. Polar Notes 8, $1-47(1968)$.

122. D. D. Anderson, J. A. Tuck, Osteology of the Dorset people. Man in the Northeast 8, 89-97 (1974).

123. S. Brown, Archaeological Investigations at Crow Head Cave and the Gargamelle Rockshelter in the Port aux Choix National Historical Park, Newfoundland (1988).

124. J. P. Howley, The Beothucks or Red Indians (Cambridge University Press, Cambridge, 1915).

125. S. Brown, in The Cultural Landscapes of Port aux Choix, M. A. P. Renouf, Ed. (Springer, New York, 2011).

126. P. J. Reimer et al., IntCal13 and Marine13 Radiocarbon Age Calibration Curves 0-50,000 Years cal BP, Radiocarbon 55, 1869-1887 (2013).

127. M. A. P. Renouf, The 1991 archaeological field season at the Port au Choix National Historic Park, unpublished report on file, (Parks Canada, Halifax, 1992).

128. J. Darwent, C. Darwent, G. LeMoine, H. Lange, Archaeological survey of eastern Inglefield Land, Northwest Greenland, Arctic Archaeology 44, 51-86 (2007).

129. G. M. LeMoine, C. M. Darwent, The Inglefield Land Archaeological Project: Introduction and Overview. Geografisk Tidsskrift 110, 279-296 (2010). 
130. C. M. Darwent, J. C. Foin, Zooarchaeological Analysis of a Late Dorset and an early Thule Dwelling at Cape Grinnell, Northwest Greenland. Geografisk Tidsskrift 110, 315-336 (2010).

131. W. E. Taylor, Jr., Archaeological Work in Ungava and Mansel Island. Arctic Circular 11, 66-67 (1959).

132. A. McCartney, Thule Eskimo Prehistory along Northwestern Hudson Bay (Archaeological Survey of Canada, 1977).

133. C. F. Merbs, Human Burials of Silumiut: A Thule Culture Site North of Chesterfield Inlet, Northwest Territories, Preliminary Report, MS number 605 (Canadian Museum of Civilization, Quebec, 1967).

134. J. B. Coltrain, M. G. Hayes, D. H. O’Rourke, Sealing, whaling, and caribou: the skeletal isotope chemistry of Eastern Arctic foragers. Journal of Archaeological Science 31, 39-57 (2004).

135. R.E. Morlan, Canadian Archaeological Radiocarbon Database (Canadian Archaeological Association, Ottawa, 2002).

136. C. F. Merbs, Eskimo Burial Studies: The Kamarvik and Silumiut Sites, Preliminary Report MS number 607 (Canadian Museum of Civilization, Quebec, 1968).

137. C. F. Merbs, W. Wilson, Anomalies and pathologies of the Sadlermiut Eskimo vertebral column. National museum of Canada Contributions to Anthropology Bulletin 180, 154-180 (1962).

138. F. de Laguna, The Prehistory of Northern North America as seen from the Yukon. (Society for American Archaeology, 1947).

139. S. Rowley, in Threads of Arctic Prehistory: Papers in Hounour of William E. Taylor Jr., D. Morrison, J-L. Pilon, Eds. (Canadian Museum of Civilization, Gatineau, 1994) pp. 361-384.

140. W. S. Laughlin, W. E. Taylor, Jr., A Cape Dorset Culture Site on the West Coast of Ungava Bay. Bulletin of the National Museum of Canada 167, 1-28 (1960).

141. L. Oschinsky, Two Recently Discovered Human Mandibles from Cape Dorset Sites on Sugluk and Mansel Islands. Anthropologica 2, 212-227 (1960).

142. L. Oschinsky The Most Ancient Eskimos: The Eskimo Affinities of Dorset Culture Skeletal Remains (University of Ottawa, Ottawa, 1964).

143. M. G. Hayes, thesis, University of Utah (2002).

144. M. G. Hayes, J. B. Coltrain, D. H. O'Rourke, in Mummies in a New Millennium: Proceedings of the $4^{\text {th }}$ World Congress on Mummy Studies, Nuuk, Greenland. Greenland, N. Lynnerup, C. Andreasen, J. Berglund, Eds. (National Museum and Archives and Danish Polar Center, Copenhagen, 2002) pp. 125-128.

145. B. Grønnow, J. F. Jensen, The Northernmost Ruins of the Globe. Eigil Knuth's Archaeological Investigations in Peary Land and Adjacent Areas of High Arctic Greenland, Meddelelser om Grønland, Man \& Society 29 (2003).

146. H. Larsen, Dødemandsbugten: An Eskimo Settlement on Clavering Island. Treaarsexpeditionen til Christian d. X's Land 1931-34, Meddelelser om Grønland 102 (1934).

147. M. Sørensen, H. C. Gulløv, The Prehistory of Inuit in Northeast Greenland. Arctic Anthropology, 49, 88-104 (2012). 
148. H. G. Bandi, J. Meldgaard, Archaeological Investigation on Clavering Ø, Northeast Greenland, Meddelelser om Grønland 126 (1952).

149. P. V. Glob, Eskimo Settlements in Kempe Fjord and King Oscar Fjord. Treaarsexpeditionen til Christian d. X's Land 1931-34, Meddelelser om Grønland 102 (1935).

150. H. Larsen, Archaeological Investigations in Knud Rasmussen Land, Meddelelser om Grønland 119 (1938).

151. T. Mathiassen, The Former Eskimo Settlements on the Frederik VI's Coast, Meddelelser om Grønland 109 (1936).

152. H. C. Gulløv et al., Illuluarsuk: Rapport om det arkaologiske feltarbejde i Illuluarsuk regionen syd for Bernstorffs Isfjord, Ammassalik kommune, Sydgrønland, sommeren 1992, Projekt Skjoldungen (National Museum of Denmark, Copenhagen, 1993).

153. J. P. H. Hansen, J. Meldgaard, J. Nordqvist, Eds., Qilakitsoq: De grønlandske mumier fra 1400-tallet (1985).

154. J. P. H. Hansen, H. C. Gulløv, The mummies from Qilakitsoq - Eskimos in the 15th century, Meddelelser om Grønland 12 (1989).

155. M. T. P. Gilbert et al., mtDNA from Hair and Nail Clarifies the Genetic Relationship of the $15^{\text {th }}$ Century Qilakitsoq Inuit Mummies, American Journal of Physical Anthropology 133, 847-853 (2007).

156. S. Grummesgaard, Thulekulturens grave. Tidsskriftet Grønland 5-6-7, 198-227 (1997).

157. E. Holtved, Archaeological Investigations in the Thule District. Meddelelser om Grønland 141 (1944).

158. D. E. Dumond, Handbook of North American Indians, D. Damas, Ed. (Smithsonian Institution Press, Washington D. C., 1984), pp. 94-105.

159. K. Britton et al., Maritime Adaptations and Dietary Variation in Prehistoric Western Alaska: Stable Isotope Analysis of Permafrost-Preserved Human Hair, American Journal of Physical Anthropology 151, 448-461 (2013).

160. S. G. Fedorova, The Russian Population in Alaska and California: Late 18th Century-1867, R. A. Pierce, A. S. Donnelly, Eds. (Limestone Press: Kingston, 1973).

161. G. Mary-Rousseliére, Nunguvik et Saatut: Sites paléoeskimaux de Navy Board Inlet, Île de Baffin, (Canadian Museum of Civilization, Gatineau, 2002).

162. J. Meldgaard, Harpoons and Lances from Iglulik, NWT, Canada (1968).

163. J. Darwent, H. Lange, G. LeMoine, C. Darwent, The Longest Longhouse in Greenland. Antiquity 83 (2008).

164. J. Darwent, T. B. Johansen, Archaeological Survey in the Foulke Fjord Region, Inglefield Land, Northwestern Greenland. Geografisk Tidsskrift 110, 297-314 (2010).

165. D. E. Dumond, The Norton Tradition, Arctic Anthropology 37, 1-22 (2002). 
166. W. Workman, Beyond the Southern Frontier: The Norton Culture and the Western Kenai Peninsula, Arctic Anthropology 19, 101-121 (1982).

167. R. A. Knecht, R. Davis, in Archaeology in the Aleut Zone: Some Recent Research, D. Dumond, Ed. (University of Oregon, Eugene, 2001), pp. 269-288.

168. K. Dneprovsky, A Late Birnirk House at Paipelghak in Northern Chukotka: A Preliminary Report based on the Excavations from 2002-2004, Alaska Journal of Anthropology 4, 34-53 (2006).

169. K. Dneprovsky, in Archaeology in the Bering Strait Region, D. Dumond, Ed. (University of Oregon, 2002), pp., 166-206.

170. K. J. Krogh, Viking Greenland (The National Museum, Copenhagen, 1967).

171. J. Arneborg et al., Norse Greenland Dietary Economy ca. AD 980-ca. AD 1450. Journal of the North Atlantic 3, 1-39 (2012).

172. P. Nørlund, Norse Ruins at Gardar, Meddelelser om Grønland LXXVI (1929).

173. A. Roussell, Farms and Churches in the Mediaeval Norse Settlements of Greenland, Meddelelser om Grønland 89 (1941).

174. A. Roussell, Sandnes and the Neighbouring Farms. Meddelelser om Grønland 88 (1936).

175. G. M. Santos, J. R. Southon, K. C. Druffel-Rodriguez, S. Griffin, M. Mazon, Magnesium perchlorate as an alternative water trap in AMS graphite sample preparation: A report on sample preparation at KCCAMS at the University of California, Irvine, Radiocarbon 46, 165-173 (2004).

176. E. M. Scott, G. T. Cook, P. Naysmith, The fifth International Radiocarbon Intercomparison (VIRI): an assessment of laboratory performance in Stage 3, Radiocarbon 52, 859-865 (2010).

177. T. W. Stafford, Jr., A. J. T. Jull, K. Brendel, R. Duhamel, D. Donahue, Study of bone radiocarbon dating accuracy at the University of Arizona NSF accelerator facility for radioisotope analysis. Radiocarbon 86, 24-44 (1987).

178. M. R. Waters, T. W. Stafford, Jr., Redefining the Age of Clovis: Implications for the Peopling of the Americas, Science 315, 1122-1126 (2007).

179. M. J. DeNiro, S. Epstein, Influence of diet on the distribution of carbon isotopes in animals, Geochim. Cosmochim. Acta 42, 341-351 (1981).

180. M. L. Jørkov, J. Heinemeier, N. Lynnerup, Evaluating bone collagen extraction methods for stable isotope analysis in dietary studies, Journal of Archaeological Science 34, 1824-1829 (2007).

181. M. J. DeNiro, Postmortem preservation and alteration of in vivo bone collagen isotope ratios in relation to palaeodietary reconstruction, Nature 317, 806-809 (1985).

182. G. J. van Klinken, Bone collagen quality indicators for palaeodietary and radiocarbon measurements, Journal of Archaeological Science 26, 687-695 (1999).

183. J. S. Vogel, J. R. Southon, D. E. Nelson, T. A. Brown, in International conference on AMS, $3^{\text {rd }}$ Proceedings: Nuclear Instruments \& Methods, W. Wölfli, H. A. Polach, H. H. Anderson, Eds. (1984), pp. 289-293. 
184. U. Zoppi et al., Forensic applications of ${ }^{14} \mathrm{C}$ bomb-pulse dating, Nuclear Instruments and Methods in Physics Research B 223-224, 770-775 (2007).

185. M. Stuiver, H. A. Polach, Discussion: reporting of ${ }^{14}$ C data. Radiocarbon 19, 355-363 (1977).

186. G. J. Andersen et al., ${ }^{14} \mathrm{C}$ dating on the Fossvogur Sediments, Iceland, Radiocarbon 31, 592-600 (1989).

187. W. Beaumont, R. Beverly, J. Southon, R. E. Taylor, Bone preparation at the KCCAMS laboratory, Nuclear Instruments and Methods in Physics Research B 268, 906-909 (2010).

188. R. Longin, New method of collagen extraction for radiocarbon dating, Nature 230, 241-242 (1971).

189. T. A. Brown, D. E. Nelson, J. S. Vogel, J. R. Southon, Improved collagen extraction by modified longin method, Radiocarbon 30, 171-177 (1988).

190. J. R. Southon, G. M. Santos, Ion source development at KCCAMS, University of California, Irvine, Radiocarbon 46, 33-39 (2004).

191. D. E. Nelson et al., An Isotopic Analysis of the Diet of the Greenland Norse, Journal of the North Atlantic 3, 93-118 (2012).

192. D. E. Nelson, J. Heinemeier, J. Møhl, J. Arneborg, Isotopic Analyses of the Domestic Animals of Norse Greenland. Journal of the North Atlantic 3, 77-92 (2012).

193. D. E. Nelson, N. Lynnerup, J. Arneborg, J., A First Isotopic Dietary Study of the Greenlandic Thule Culture. Journal of the North Atlantic 3, 51-64 (2012).

194. D. E. Nelson, J. Møhl, J. Heinemeier, J. Arneborg, J., Stable Carbon and Nitrogen Isotopic Measurements of the Wild Animals Hunted by the Norse and the Neo-Eskimo People of Greenland. Journal of the North Atlantic 3, 40-50 (2012).

195. M. Sponheimer et al., Nitrogen isotopes in mammalian herbivores: Hair delta N-15 values from a controlled feeding study, International Journal of Osteoarchaeology 13, 80-87 (2003).

196. D. C. Barber et al., Forcing of the cold event of 8,200 years ago by catastrophic drainage of Laurentide lakes. Nature 400, 344-348 (1999).

197. S. E. Campana, Use of radiocarbon from nuclear fallout as a dated marker in the otoliths of haddock Melanogrammus aeglefinus, Marine Ecology Progress Series 150, 49-56 (1997).

198. R. D. Coulthard et al., New marine Delta R values for Arctic Canada, Quaternary Geochronology 5, 419-434 (2010).

199. A. S. Dyke, in Quaternary Glaciations- Extent and Chronology, Part II, J. Ehlers, P. L. Gibbard, Eds. (Elsevier, 2004), pp. 373-424.

200. R. McNeely, A. S. Dyke, J. R. Southon, Canadian marine reservoir ages, preliminary data assessment, Open File 5049 (Geological Survey Canada, 2006).

201. N. A. Mårner, S. Funder, Late Quaternary stratigraphy and glaciology in the Thule area, Northwest Greenland, Meddelelser om Grønland, Geoscience 22, 57-63 (1990). 
202. I. U. Olsson, Content of ${ }^{14} \mathrm{C}$ in marine mammals from northern Europe. Radiocarbon 22, 662-675 (1980).

203. P. J. Reimer, R. W. Reimer, A marine reservoir correction database and on-line interface, Radiocarbon 43, 461-463 (2001).

204. C. Bronk Ramsey, Bayesian analysis of radiocarbon dates, Radiocarbon 51, 337-360 (2009).

205. M. T. P. Gilbert et al., Whole-Genome Shotgun Sequencing of Mitochondria from Ancient Hair Shafts, Science 317, 1927-1930 (2007).

206. H. Malmström et al., More on Contamination: The Use of Asymmetric Molecular Behavior to Identify Authentic Ancient Human DNA, Molecular Biology and Evolution 24, 998-1004 (2007).

207. L. Melchior et al., Rare mtDNA haplogroups and genetic differences in rich and poor Danish Iron-Age villages, Am. J. Phys. Anthropol 135, 206-215 (2008).

208. D. Y. Yang, B. Eng, J. S. Waye, J. C. Dudar, S. R. Sanders, Technical Note: Improved DNA Extraction from Ancient Bones Using Silica-Based Spin Columns, Am. J. Phys. Anthropol. 105, 539-543 (1998).

209. E. M. Svensson et al., Tracing genetic change over time using nuclear SNPs in ancient and modern cattle. Anim. Genet. 38, 378-383 (2007).

210. J. Saillard et al., mtDNA Variation among Greenland Eskimos: The Edge of the Beringian Expansion, The American Journal of Human Genetics 67, 718-726 (2000).

211. A. Helgason et al., mtDNA variation in Inuit populations of Greenland and Canada: Migration history and population structure, American Journal of Physical Anthropology 130, 123-134 (2006).

212. J. A. Raff et al., Ancient DNA perspectives on American colonization and population history, American Journal of Physical Anthropology 146, 503-514 (2011).

213. E. Tamm et al., Beringian stand- still and spread of Native American founders, PLoS ONE 2:e829 (2007).

214. A. O. Karlsson, G. Holmlund, Identification of mammal species using species-specific DNA pyrosequencing, Forensic Science International 173, 16-20 (2007).

215. R. M. Andrews et al., Reanalysis and revision of the Cambridge reference sequence for human mitochondrial DNA, Nat Genet 23, 147 (1999).

216. D. H. Alexander, J. Novembre, K. Lange, Fast model-based estimation of ancestry in unrelated individuals, Genome Res. 19, 1655-1664 (2009).

217. I. Moltke, A. Albrechtsen, RelateAdmix: a software tool for estimating relatedness between admixed individuals, Bioinformatics (2013), doi: 10.1093/bioinformatics/btt652.

218. S. A. Fedorova et al., Autosomal and uniparental portraits of the native populations of Sakha (Yakutia): implications for the peopling of Northeast Eurasia, BMC Evolutionary Biology 13, 127-144 (2013). 
219. A. Manichaikul et al., Robust relationship inference in genome-wide association studies, Bioinformatics 26, 2867-2873 (2010).

220. N. Rosenberg et al., Standardized subsets of the HGDP-CEPH Human Genome Diversity Cell Line Panel, accounting for atypical and duplicated samples and pairs of close relatives, Annals of Human Genetics 70, 841-847 (2006).

221. A. Albrechtsen et al., Relatedness mapping and tracts of relatedness for genome-wide data in the presence of linkage disequilibrium, Genetic Epidemiology 33, 266-274 (2009).

222. S. Purcell et al., PLINK: a tool set for whole-genome association and population-based linkage analyses, Am J Hum Genet 81, 559-575 (2007).

223. S. Lindgreen, AdapterRemoval: easy cleaning of next-generation sequencing reads, BMC Res Notes $\mathbf{5}$, 337 (2012).

224. H. Li, R. Durbin, Fast and accurate short read alignment with Burrows-Wheeler transform, Bioinformatics 25, 1754-1760 (2009).

225. H. Li et al., The Sequence Alignment/Map format and SAMtools, Bioinformatics 25, 2078-2079 (2009).

226. M. A. DePristo et al., A framework for variation discovery and genotyping using next-generation DNA sequencing data, Nat Genet 43, 491-498 (2011).

227. A. R. Quinlan, I. M. Hall, BEDTools: a flexible suite of utilities for comparing genomic features, Bioinformatics 26, 841-842 (2010).

228. J. E. Wigginton, D. J. Cutler, G. R. Abecasis, A note on exact tests of Hardy-Weinberg equilibrium, Am J Hum Genet 76, 887-893 (2005).

229. J. Krause, et al., A complete mtDNA genome of an early modern human from Kostenki, Russia. Curr. Biol. 20, 231-236 (2010).

230. L. Orlando et al., Recalibrating Equus evolution using the genome sequence of an early Middle Pleistocene horse, Nature 499, 74-78 (2013).

231. T. F. Cox, M. A. A. Cox, Multidimensional Scaling (Chapman and Hall, 2000).

232. H. Tang et al., Estimation of individual admixture: analytical and study design considerations, Genet Epidemiol 28, 289-301 (2005).

233. E. Y. Durand, N. Patterson, D. Reich D, M. Slatkin, Testing for ancient admixture between closely related populations, Mol Biol Evol 28, 2239-2252 (2011).

234. D. Reich et al., Genetic history of an archaic hominin group from Denisova Cave in Siberia, Nature 468, 1053-1060 (2010).

235. F. T. M. A. Busing, E. Meijer, R. van der Leeden, Delete-m Jackknife for Unequal m. Statistics and Computing 9, 3-8 (1999).

236. R. R. Hudson, Generating samples under a Wright-Fisher neutral model, Bioinformatics 18, 337-378 (2002).

237. B. K. Maples, S. Gravel, E. E. Kenny, C. D. Bustamante, RFMix: A discriminative modeling approach for rapid and robust local-ancestry inference. American Journal of Human Genetics 93, 278-288 (2013). 
238. A. Ginolhac, M. Rasmussen, M. T. P. Gilbert, E. Willerslev, L. Orlando, mapDamage: testing for damage patterns in ancient DNA sequences. Bioinformatics 27, 2153-2155 (2011).

239. M. Rasmussen et al., An Aboriginal Australian genome reveals separate human dispersals in Asia, Science 334, 94-98 (2011).

240. M. T. P. Gilbert et al., DNA from Pre-Clovis Human Coprolites in Oregon, North America, Science 320, 786 (2008). 


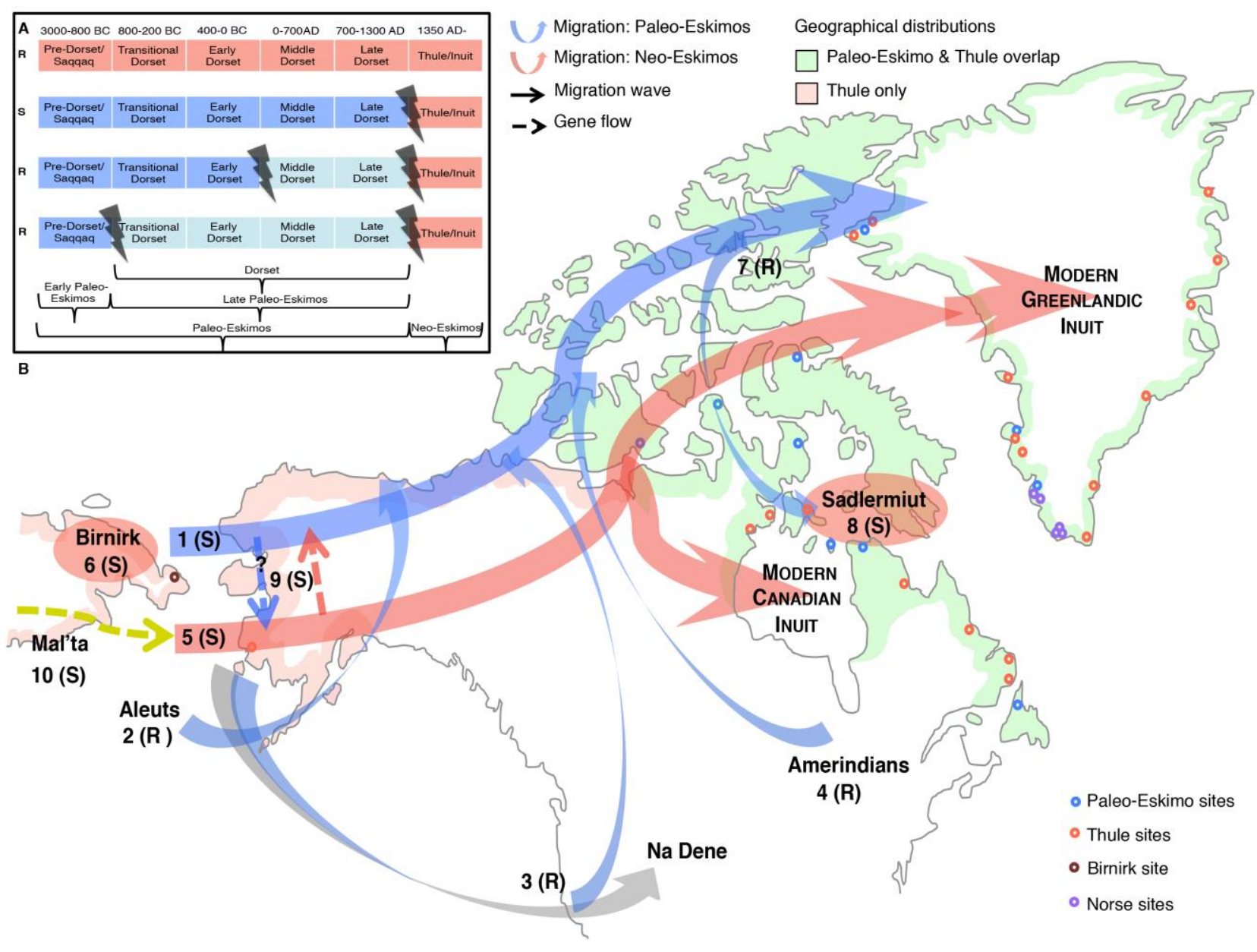



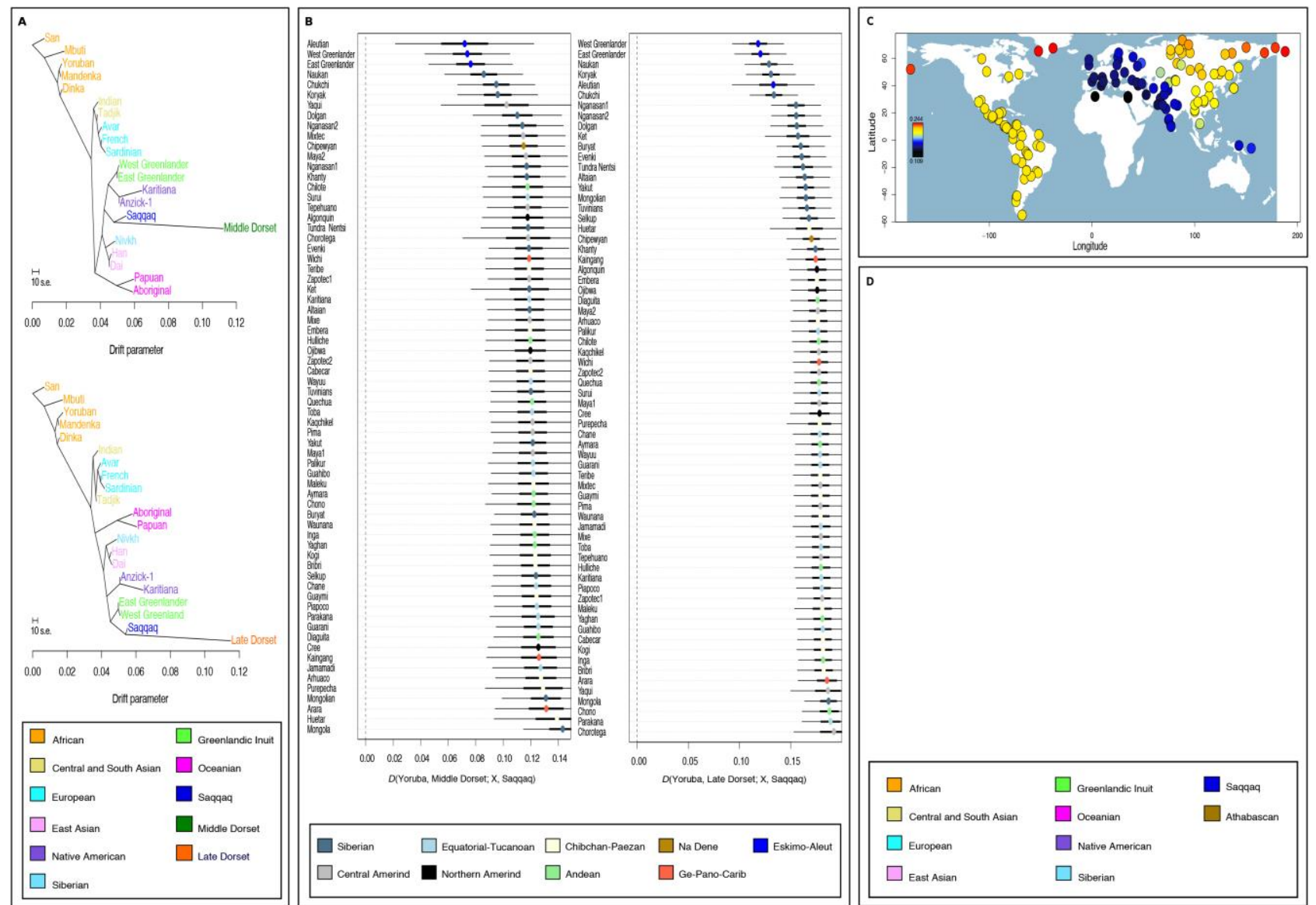


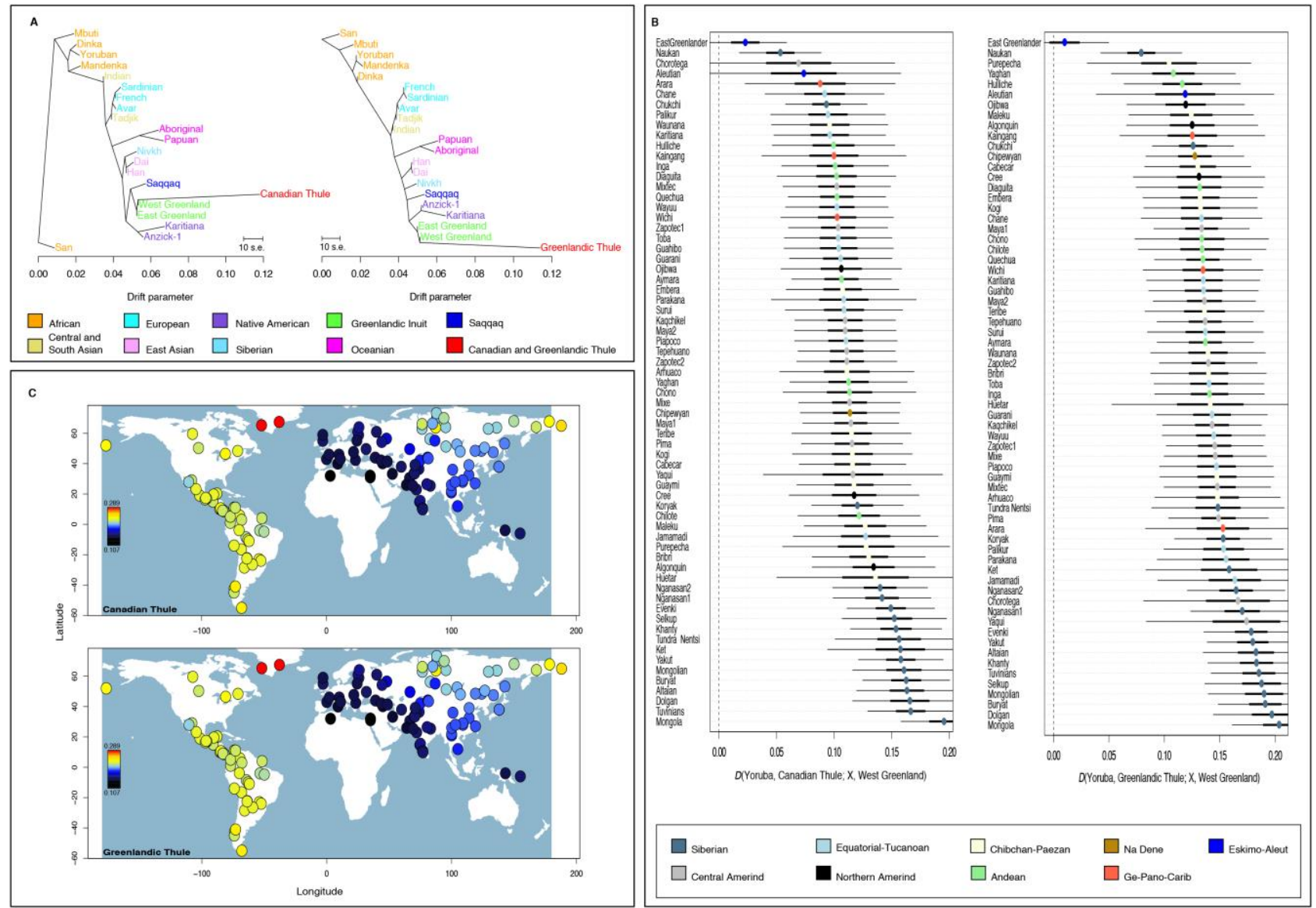



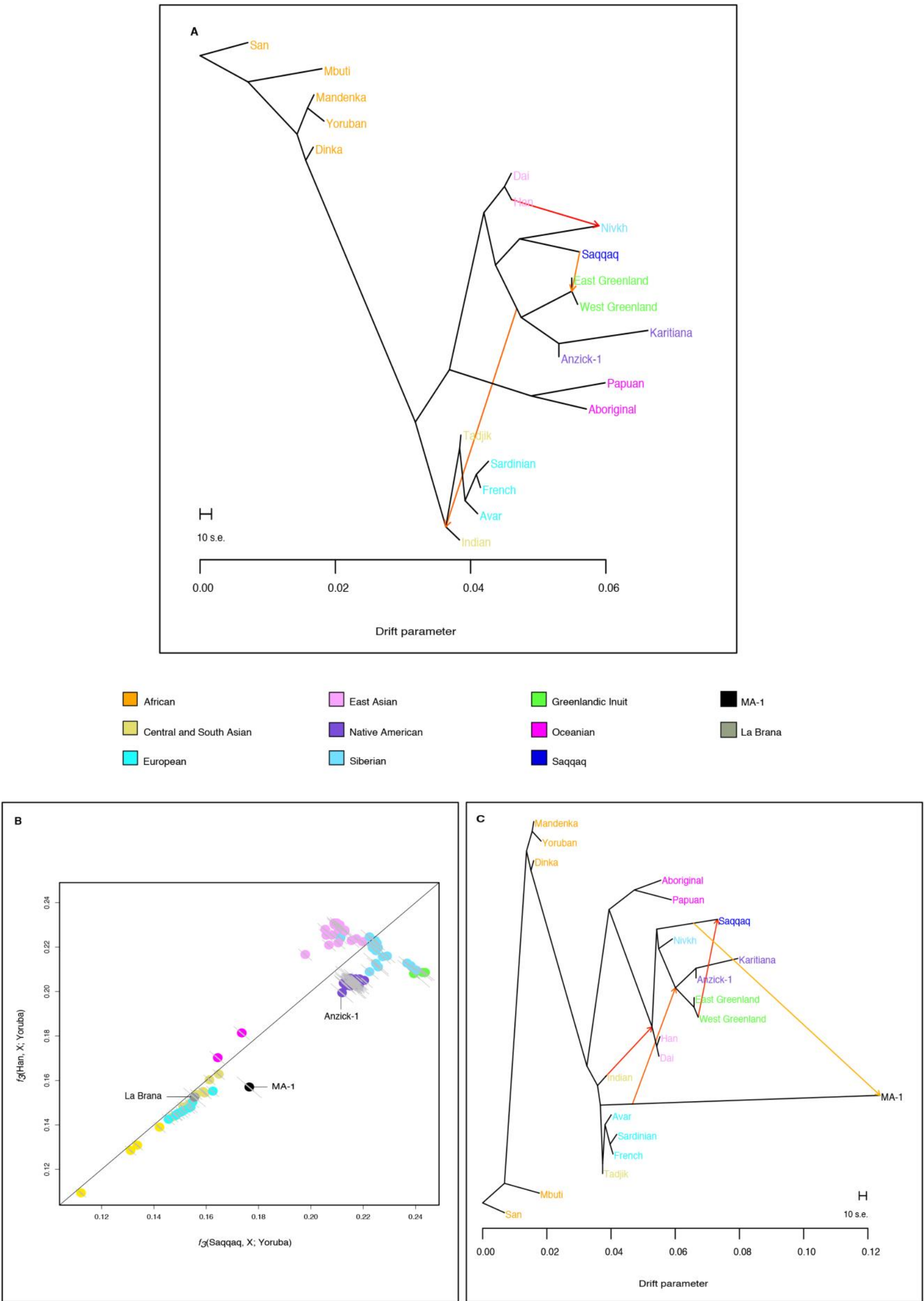